\title{
Editorial
}

\section{Axiologies, epistemologies and the worlds of practice learning}

I am pleased to welcome you to the current issue of the Journal. The world of work-based learning is growing fast and the knowledge gained during learning in practice or work settings is now accepted as part of the range of legitimate knowledges not only across the helping professions but throughout industry and higher education globally. The field of work-based learning becomes, therefore, centrally important in economic terms as well as pedagogic ones as we seek to build the evidence base, structures for assessment, future learning and for change.

The axiologies underpinning these approaches to work-based learning, field education, practice learning (and other terms employed to describe this plurality of learning types) also remain important. As the doxa, which Bourdieu uses to describe the common-sense assumptive world, of knowledges is accepted across the field, it will become fundamental to address the values that guide and develop its operation and make these clear and open to critique and theorisation.

The mix of papers in the current issue represents developments in the epistemologies and practices of the field and the search for values. Cathi Jaspar, Liz Munro, Pauline Black and Hugh McLaughlin consider the importance of innovation, challenging the boundaries set by tradition to ensure practice education in social work remains current. In the second paper, Sabina Leitmann and Marion Palmer explore how Australian students construct their own learning through the creative use of learning plans. In our third paper, Jackie Plenty and David Gower illuminate the evolutionary aspects of learning in practice and supporting that learning

3 J. of Practice Teaching \& Learning 12(1), p.3-4. DOI: 10.1921/6302120205. (๑) wEb 
through training and education for those facilitating and assessing in practice. Whilst these papers focus on social work as a discipline, they are questions raised in respect of work based and field education across the disciplines.

Our final two papers in this edition form part of our practice reflections section. The first paper, by Finnish scholars Sisko Piippo, Juha Hämäläinen, Anssi Savolainen, Mari Suonio, and Raija Väisänen highlights the need for the traditional producers of knowledge and the practice settings to come together to construct a new crucible in which learning can be melded. In the second paper, Sheila Cooper and Maura Daly espouse participatory and strengths-based values, offering insights from alcohol and substance use services that may be transferred across learning settings.

I hope, whatever your discipline and background, that this issue is enjoyed and that ideas are spawned which result in debate, amplification and challenge.

\section{Prof Jonathan Parker}

4 J. of Practice Teaching \& Learning 12(1), p.3-4. DOI: 10.1921/6302120205. () w\&-b 